\title{
Changes in trophic community structure of shore fishes at an industrial site in the Gulf of Aqaba, Red Sea
}

\author{
M. A. Khalaf ${ }^{1}$, M. Kochzius ${ }^{2, *}$ \\ ${ }^{1}$ Marine Science Station, PO Box 195, Aqaba, Jordan \\ ${ }^{2}$ Centre for Tropical Marine Ecology-ZMT, Fahrenheitstrasse 6, 28359 Bremen, Germany
}

\begin{abstract}
The semi-enclosed Gulf of Aqaba is under high pressure by urban and industrial pollution, shipping and port activities as well as tourism. Off the Jordanian Red Sea coast, the trophic community structure of shore fishes was determined on coral reefs in front of an industrial area (disturbed), in a marine reserve and site without industry or port activities (undisturbed), as well as in a seagrass-dominated bay. Planktivores were the most abundant feeding guild on coral reefs as well as in the seagrass-dominated bay. The relative abundance of feeding guilds other than planktivores seems to be strongly influenced by the benthic habitat. Multivariate analysis clearly separated disturbed from undisturbed sites, whereas univariate measures, such as species richness, diversity and evenness did not reveal any negative impact of disturbance. The disturbance of the coral reefs led to changes in the fish community through the reduction of total fish abundance by $50 \%$, increased total abundance of herbivorous and detritivorous fishes, decreased total abundance of invertebrate- and fish-feeders, and increased relative abundance of planktivorous fishes.
\end{abstract}

KEY WORDS: Trophic community structure $\cdot$ Pollution $\cdot$ Shore fishes $\cdot$ Coral reef $\cdot$ Seagrass meadow $\cdot$ Red Sea

Resale or republication not permitted without written consent of the publisher

\section{INTRODUCTION}

The semi-enclosed Gulf of Aqaba is under high pressure by urban and industrial pollution (Mergner 1981, Walker \& Ormond 1982, Abu-Hilal 1987, Abu-Hilal \& Badran 1990, Abelson et al. 1999), shipping and port activities (Fishelson 1973, Loya 1975, Abu-Hilal 1985, Badran \& Foster 1998) as well as tourism (Riegl \& Velimirov 1991, Hawkins \& Roberts 1994). The Jordanian coastline has a length of about $27 \mathrm{~km}$ with a discontinuous series of fringing reefs of $13 \mathrm{~km}$ length, interrupted by bays which are mostly covered with seagrass meadows (UNEP/IUCN 1988). During the last

${ }^{*}$ Corresponding author. Present address: Biotechnology and Molekular Genetics, UFT-FB2, University of Bremen, Leobener Strasse, 28359 Bremen, Germany.

E-mail: kochzius@uni-bremen.de
$25 \mathrm{yr}, 30$ to $40 \%$ of the Jordanian coastline has been altered from a pristine natural environment to a heavily used port and industrial area (Abu-Hilal 1997). In 2001, Aqaba was declared a Special Economic Zone, and therefore rapid increase in port and industrial activities is to be expected.

Industry and port activities are expected to disturb the coastal ecosystem, which will lead to changes in the fish community. On the one hand, degradation of coral reefs leads to coral death, loss of the complex habitat structure and decrease of associated invertebrates, on the other hand, algal growth is enhanced due to open substrate caused by coral decease and, in some cases, eutrophication. Fishes that depend on corals or associated invertebrates as a source of food are likely to be reduced, whereas planktivores, herbivores and detritivores can increase in relative abundance so long as the dead corals still provide shelter. 


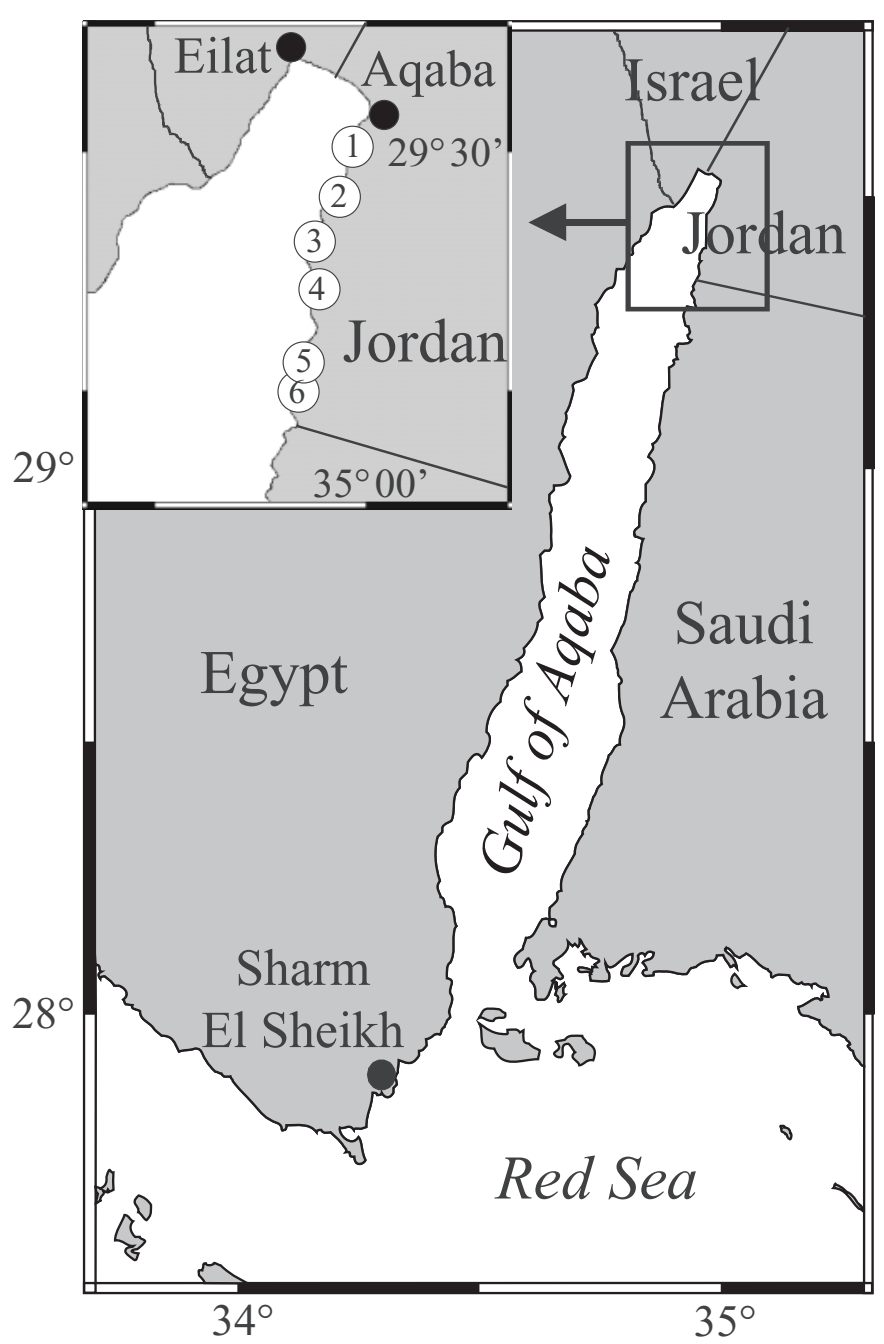

Fig. 1. Gulf of Aqaba, showing study sites along Jordanian coast. 1: cement jetty $\left(29^{\circ} 28.990^{\prime} \mathrm{N}, 34^{\circ} 59.010^{\prime} \mathrm{E}\right)$; 2 : Marine Science Station $\left(29^{\circ} 27.250^{\prime} \mathrm{N}, 34^{\circ} 58.359^{\prime} \mathrm{E}_{\text {; }}\right.$ distance from Site $1 .=3.4 \mathrm{~km}) ; 3$ : tourist camp $\left(\mathrm{N} 29^{\circ} 26.351^{\prime} \mathrm{N}, 34^{\circ} 58.272^{\prime} \mathrm{E}_{\text {; dis- }}\right.$ dis tance from Site $2=1.6 \mathrm{~km}) ; 4$ : Al-Mamlah Bay $\left(29^{\circ} 24.345^{\prime} \mathrm{N}\right.$, $34^{\circ} 58.549^{\prime} E_{\text {; }}$ distance from Site $3=3.7 \mathrm{~km}$ ) 5 , 6: Jordan Fertiliser Industries and Jordan Fertiliser Industries jetty $\left(29^{\circ} 22.134^{\prime} \mathrm{N}, 34^{\circ} 57.667^{\prime} \mathrm{E}\right.$; distance from Site $\left.4=4.1 \mathrm{~km}\right)$

Investigations of the impact of coral mining (Shepherd et al. 1992) and coral bleaching (Lindahl et al. 2001) on fish communities have shown that univariate measures, such as species richness and diversity, are not appropriate to reveal changes in the fish community. Therefore, we investigated the trophic community structure of fishes on disturbed as well as undisturbed coral reefs, and in a seagrass-dominated bay along the Jordanian coast. The disturbed reefs are located in front of an industrial area and port, whereas the undisturbed reefs are situated in a marine reserve and at sites with no industry or port activity.

\section{MATERIALS AND METHODS}

Study sites. Our investigation of the general trophic community structure of shore fishes in the Gulf of Aqaba is based on 5 coral reefs and the seagrass-dominated Al-Mamlah Bay at the Jordanian coast (Fig. 1). The degree of human-induced disturbance differs greatly along the coastline. The sites regarded as undisturbed are completely closed for human activities (marine reserve) or utilised for small-scale fishing as well as recreational activities. At the disturbed sites, the fringing reef in front of the Jordan Fertiliser Industries (JFI) is under pressure due to port activity, solid waste disposal, spillage during loading and unloading of ships (e.g. sulphur, ammonia), as well as disposal of waste oil from trucks (Gladstone et al. 1999) (see Table 1). In the past, parts of the reef flat were filled in for a parking place and the JFI jetty (Mahasneh \& Meinesz 1984). A study on coral diseases revealed a 10 -fold higher number of infected coral colonies at the JFI than in the marine reserve (Al-Moghrabi 2001). Values of phosphate concentrations (Badran \& Foster 1998), heavy metals (Abu Hilal \& Badran 1990), and algal cover (M.A.K. pers. obs.) are higher at the disturbed JFI than in the marine reserve at the Marine Science Station (MSS). Phosphate concentrations at JFI reach the threshold value of 0.1 to $0.2 \mu \mathrm{M}$, a level proposed as indicating polluted (Bell 1992). The distance between the disturbed and undisturbed sites is around $8 \mathrm{~km}$.

Visual census. The fish communities in shallowwater habitats along the Jordanian coast were surveyed by the visual census technique using SCUBA, as described by English et al. (1994). Transects of $50 \mathrm{~m}$ length and $5 \mathrm{~m}$ width $\left(250 \mathrm{~m}^{2}\right)$ were marked along lines at 6 sites parallel to the shore (Fig. 1, Table 2). At each site, visual censuses were conducted along 3 transects on the shallow reef slope $(6 \mathrm{~m})$ and deep reef slope $(12 \mathrm{~m})$, respectively. The distance between the transects at each site was 10 to $20 \mathrm{~m}$. After laying the transect line, an observer would wait 5 to $10 \mathrm{~min}$ to allow fishes to resume their normal behaviour. Subsequently the diver swam 50 to 60 min along the transect and recorded all fishes encountered $2.5 \mathrm{~m}$ on each site of the line and $5 \mathrm{~m}$ above the transect. Differences in the skill and technique of the observers are a source of imprecision and/or bias (Thompson \& Mapstone 1997). Therefore, the first author (M.A.K.) identified and recorded all fishes of about $30 \mathrm{~mm}$ total length or larger on a plastic slate. The visual census technique is widely applied and accepted for ecological fish studies on coral reefs (English et al. 1994). However, all our conclusions are restricted to diurnally active and noncryptic species (Brock 1982). At 5 sites (cement jetty, Marine Science Station, tourist camp, Jordan Fertiliser 
Table 1. Human-induced disturbance on coral reefs along Jordanian Red Sea coast, Gulf of Aqaba

\begin{tabular}{|lccl|}
\hline Site & State & Human impact & \multicolumn{1}{c|}{ Activities } \\
\hline Cement jetty & Undisturbed & Medium & Some fishing (hook and line) \\
Marine Science Station & Undisturbed & Very low & Marine reserve; occasionally illegal fishing \\
Tourist camp & Undisturbed & Low & Swimming and snorkeling \\
$\begin{array}{l}\text { Jordan Fertiliser } \\
\text { Industries }\end{array}$ & Disturbed & Very high & $\begin{array}{l}\text { High port activity; solid waste; phosphate and trace metal pollution, } \\
\text { sedimentation }\end{array}$ \\
$\begin{array}{l}\text { Jordan Fertiliser } \\
\text { Industries jetty }\end{array}$ & Disturbed & Very high & $\begin{array}{l}\text { Very high port activity; solid waste; phosphate and trace metal } \\
\text { pollution; accidental discharge of sulphur and ammonia, sedimentation }\end{array}$ \\
& & & \\
\hline
\end{tabular}

Industries and Jordan Fertiliser Industries jetty) 3 censuses were conducted at each depth in November 1999 and March 2000. In 1997 and 1998, 39 censuses were conducted at Al-Mamlah Bay at $6 \mathrm{~m}$ depth and 43 census at $12 \mathrm{~m}$ depth (Table 2). A total of 212349 fishes were counted, representing 198 species belonging to 121 genera and 43 families. Affiliation of species with trophic groups is based on Khalaf \& Disi (1997) and on field observations (Table 3).

Statistical analysis. Community indices such as fish abundance, species richness (number of species), Shannon-Wiener diversity $\left(H^{\prime} ;\right.$ ln basis), and Pielou's evenness $\left(J^{\prime}\right)$ were compared among sites and depths using 1-way ANOVA. Homogeneity of variances was tested with the F-test and, if necessary, data were $\log (1+x)$-transformed to obtain homogeneity of variances. If transformation of the data did not lead to homogeneity of variances, no statistical test was conducted. The F-test was performed with a spreadsheet analysis programme, and 1-way ANOVA was carried out with STATISTICA 5.1 (StatSoft 1997).

Multivariate analysis of the data such as cluster analysis, MDS (multi-dimensional scaling), ANOSIM (analysis of similarities) significance test, as well as SIMPER (similarity percentages) were performed with PRIMER 5 software (Primer-E 2000). Hierarchical clustering and MDS was based on Bray-Curtis similarities. In contrast to species with very low abundance, highly abundant species can disturb an analysis. Therefore, when necessary, data were standardised (see Fig. 4A,B).

MDS is a 3-dimensional ordination of samples brought down to a 2-dimensional plot. The quality of the MDS plot is indicated by its stress value: values $<0.2$ give a potentially useful 2-dimensional picture, stress $<0.1$ corresponds to a good ordination, and stress $<0.05$ is an excellent representation.

The ANOSIM significance test compares similarities of species compositions between samples and can give evidence of differences. Global R indicates the degree of similarity between the tested groups, with values between -1 and 1 . If all replicates within sites are more similar to each other than any replicate from different sites, the value of $\mathrm{R}$ is 1, values close to zero indicate that the similarity between sites is very high. A 1-way layout of ANOSIM was performed with the original data, no transformation or standardisation was conducted.

SIMPER is an analytical tool used to reveal the average Bray-Curtis dissimilarity between groups of samples. The aim of the analysis in our study was to calculate the contribution of each feeding guild to the differences between sites (Clarke \& Warwick 1994).

\section{RESULTS}

\section{Fish community parameters (Fig. 2)}

Species richness showed no difference between disturbed and undisturbed coral reefs. Diversity $\left(H^{\prime}\right)$ and evenness $\left(J^{\prime}\right)$ were higher at the disturbed sites, whereas fish abundance on disturbed reefs was $51.4 \%$ lower than on undisturbed reefs.

\section{Relative species richness and relative abundance of trophic groups (Table 4)}

In terms of number of species belonging to different feeding guilds, predators on invertebrates $(25.3 \%)$

Table 2. Sampling sites along Jordanian Red Sea coast, Gulf of Aqaba

\begin{tabular}{|lccrc|}
\hline Site & $\mathrm{n}$ & $6 \mathrm{~m}$ & $\mathrm{n}$ & $12 \mathrm{~m}$ \\
\hline Cement jetty & 3 & Nov 1999 & 3 & Nov 1999 \\
Marine Science Station & 3 & Nov 1999 & 3 & Nov 1999 \\
Tourist camp & 3 & Nov 1999 & 3 & Nov 1999 \\
Al-Mamlah Bay & 39 & Apr 1997- & 43 & Apr 1997- \\
$\begin{array}{l}\text { Jurdan Fertiliser } \\
\quad \text { Industries }\end{array}$ & 3 & Apr 2000 & 3 & Apr 1999 2000 \\
$\begin{array}{l}\text { Jordan Fertiliser } \\
\text { Industries jetty }\end{array}$ & 3 & Apr 2000 & 3 & Mar 2000 \\
& & & & \\
\hline
\end{tabular}




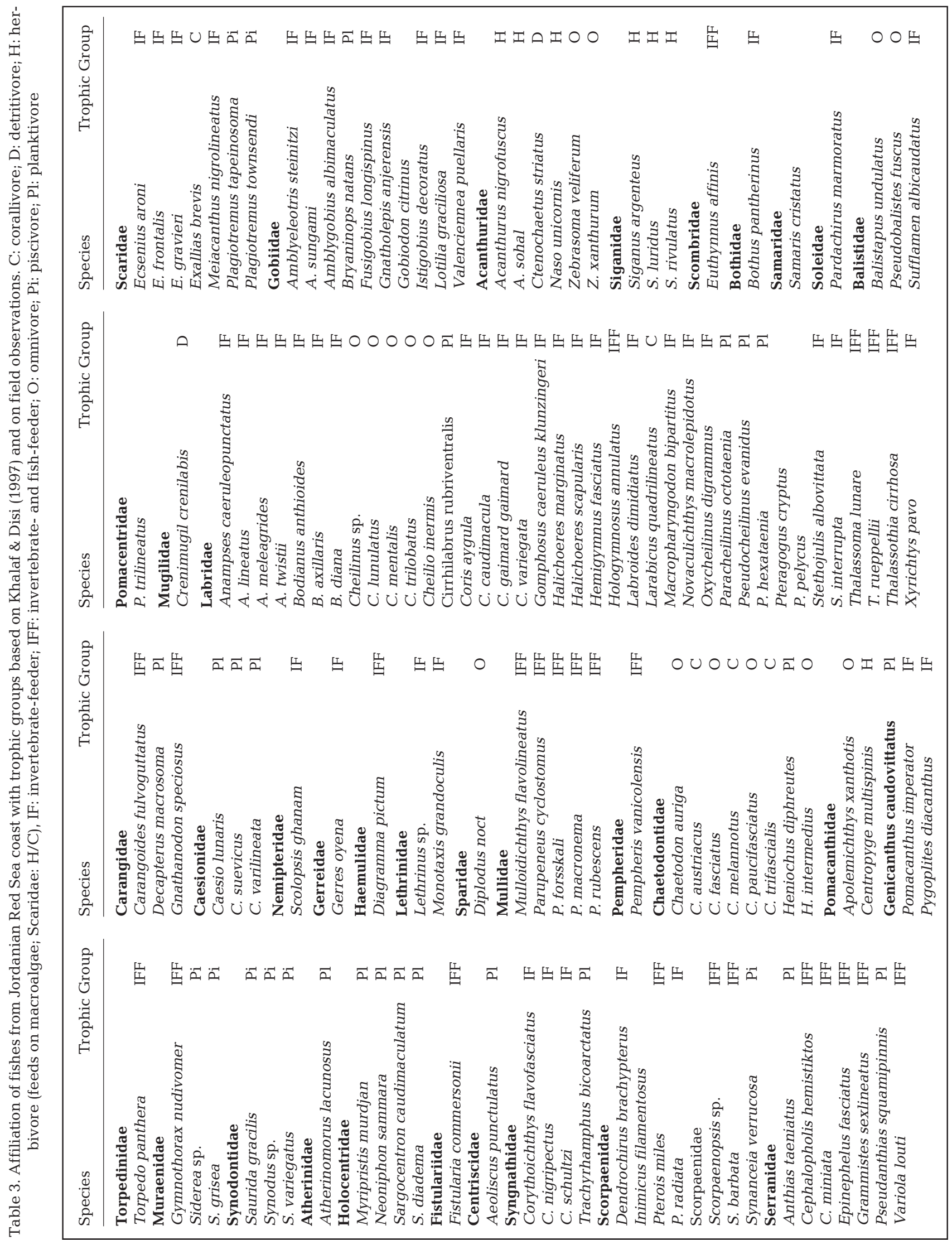




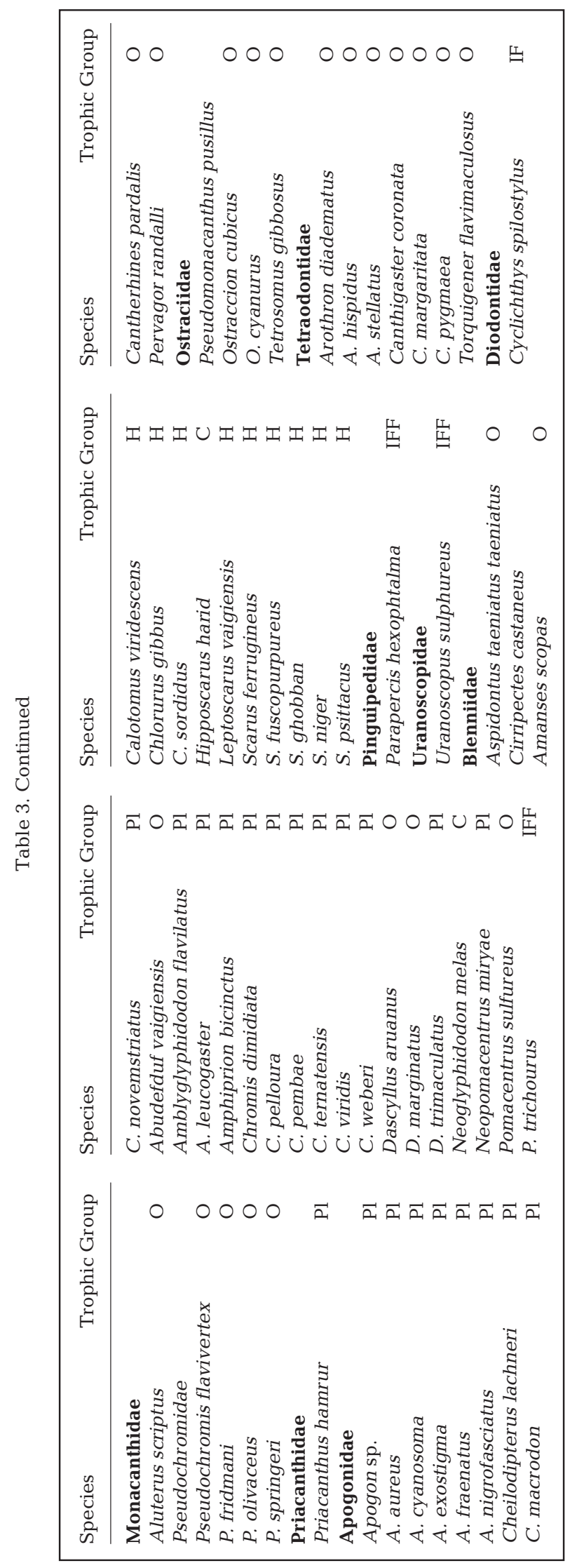

were the most common feeding guild, followed by planktivores $(20.8 \%)$ and omnivores $(19.2 \%)$.

In terms of relative abundance, $58.1 \%$ of all fish specimens were planktivorous on coral reefs, and as much as $79.9 \%$ in the seagrass-dominated Al Mamlah Bay. Other important trophic groups on coral reefs were invertebrate- and fish-feeders $(23.1 \%)$, omnivores fishes $(11.6 \%)$ and herbivores $(3.4 \%)$. These 3 groups showed a low relative abundance (5 to $6.5 \%$ ) at Al Mamlah Bay.

\section{Totale abundance of trophic groups (Fig. 3 \& Table 5)}

The total abundance of the various trophic groups at the different sites revealed patterns connected with the benthic habitat or disturbance at the respective sites. Those patterns were all statistically highly significant.

Corallivores were less abundant at the seagrassdominated site than on coral reefs. Planktivores were more abundant at $12 \mathrm{~m}$ than at $6 \mathrm{~m}$ depth on both the coral reefs and at the seagrass-dominated site. The abundance of planktivores at $12 \mathrm{~m}$ depth was higher on undisturbed coral reefs than on disturbed reefs, and was higher in the seagrass meadow than on coral reefs.

In the seagrass-dominated Al-Mamlah Bay and on the disturbed coral reefs, herbivores were more abundant at $6 \mathrm{~m}$ than at $12 \mathrm{~m}$ depth. Comparison of herbivores in $6 \mathrm{~m}$ depth between disturbed and undisturbed coral reefs revealed a higher abundance for disturbed reefs.

The number of detritivores was higher on coral reefs than in the seagrass meadow. Disturbed coral reefs tended to have a larger population of detritivores than undisturbed reefs, especially on the shallow reef slope.

Invertebrate- and fish-feeders were more abundant on coral reefs, and their numbers were higher on undisturbed than on disturbed coral reefs, especially on the shallow reef slope.

Invertebrate-feeders had a larger population in the seagrass meadow.

In the seagrass-dominated Al-Mamlah Bay, piscivores were higher in abundance at $12 \mathrm{~m}$ than at $6 \mathrm{~m}$. In addition, the population of piscivores at $12 \mathrm{~m}$ was larger than on coral reefs.

Omnivores tended to be more abundant on the deep reef slope than on the shallow reef slope, but there was no significant difference between sites.

\section{Multivariate analysis}

The cluster analysis and the MDS plot based on abundance of feeding guilds on coral reefs on the shal- 

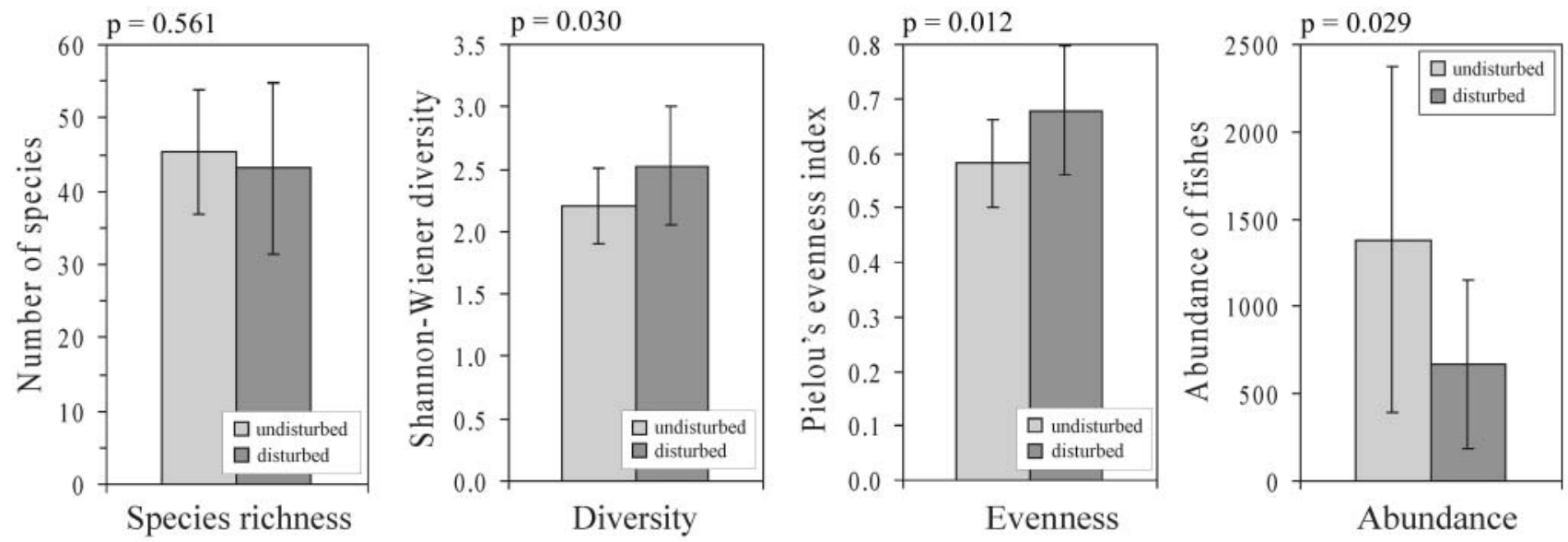

Fig. 2. Fish community parameters (species richness, diversity, eveness, abundance) of undisturbed and disturbed coral reefs at the Jordanian Red Sea coast, Gulf of Aqaba. Bold-face = significant values (1-way ANOVA)

low $(6 \mathrm{~m})$ and deep $(12 \mathrm{~m})$ reef slope revealed 2 clusters: (1) disturbed, and (2) undisturbed coral reefs (Fig. 4). Analysis of the shallow reef slope showed 2 mismatches (Samples 6a: Fig. 4), but these did not affect the general pattern. A dendrogram and MDS plot of the deep reef slope communities included 2 mismatches at disturbed reefs (Samples $1 \mathrm{~b}$ and $2 \mathrm{~b}$ ) without affecting the division into the 2 groups. An ANOSIM test confirmed the pattern of both multivariate analyses (Fig. 4). The dendrogram and MDS plot for species abundance were more or less identical to the multivariate analysis of feeding guilds, and are therefore not presented here.

SIMPER analysis revealed that invertebrate- and fish-feeders $(48.4 \%)$ and planktivores $(41.3 \%)$ were the main feeding guilds responsible for differences in community structure between disturbed and undisturbed shallow reef slopes. Invertebrate feeders $(4.2 \%)$, herbivores $(3.1 \%)$ and omnivores $(1.7 \%)$ con-

Table 4. Trophic composition of fish fauna in shallow water habitats along Jordanian Red Sea coast, Gulf of Aqaba

\begin{tabular}{|lrrrr|}
\hline \multirow{2}{*}{ Feeding guilds } & \multicolumn{3}{c}{ Species richness } & \multicolumn{2}{c|}{ Relative abundance $(\%)-1$} \\
\cline { 4 - 5 } & $\mathrm{n}$ & $\%$ & Coral reef & Seagrass-dominated bay \\
\hline Corallivores & 7 & 3.5 & 0.8 & 0.1 \\
Herbivores & 17 & 8.6 & 3.4 & 6.5 \\
Planktivores & 41 & 20.8 & 58.1 & 0.1 \\
Detritivores & 2 & 1.0 & 0.5 & 5.5 \\
Invertebrate- & 28 & 14.1 & 23.1 & 2.5 \\
$\quad$ and fish-feeders & & & & \\
Invertebrate & 50 & 25.3 & 2.3 & 5.0 \\
$\quad$ feeder & & & & 0.2 \\
Omnivores & 38 & 19.2 & 11.6 & 0.2 \\
Piscivores & 8 & 4.0 & 0.1 & \\
Unknown & 7 & 3.5 & 0.0 & \\
& & & & \\
\hline
\end{tabular}

tributed a minor percentage to the dissimilarity between the 2 groups (Table 6 ). On deep reef slopes, planktivores (64.2\%) and invertebrate- and fish-feeders $(23.5 \%)$ contributed most of the dissimilarity between undisturbed and disturbed sites, whereas omnivores $(7.4 \%)$, herbivores $(2.1 \%)$ and invertebratefeeders $(1.2 \%)$ played a minor role (Table 6$)$.

\section{Trophic structure of fish fauna on disturbed and undisturbed coral reefs (Fig. 5)}

Fish communities on the shallow slope of disturbed coral reefs showed a higher relative abundance of planktivores and herbivores than undisturbed reefs, whereas the relative abundance of omnivores and fish and invertebrate feeders was reduced at the disturbed sites. On the deep reef slope the picture is not so clear. The relative abundance of planktivores and invertebrate- and fish-feeders was reduced at the disturbed coral reef, whereas omnivores and herbivores showed a higher relative abundance.

\section{DISCUSSION}

Fish counts took place at the disturbed site in March and April 2000, and at the undisturbed sites in November 1999. The possibility of the differences detected being due to seasonal changes within the fish community was considered. Our study on the community structure of shore fishes of the Jordanian coast (Khalaf 
(A)

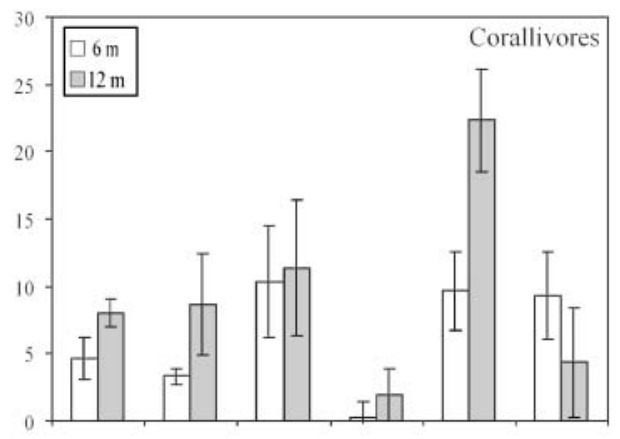

(B)

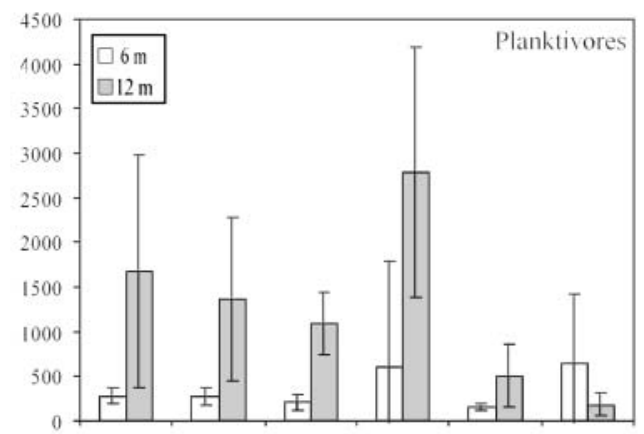

(C)

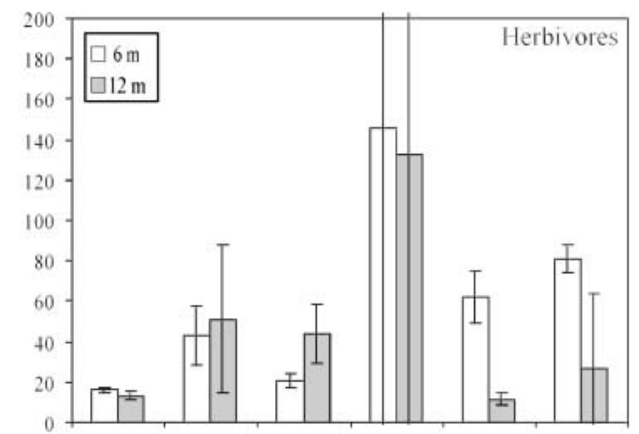

(D)

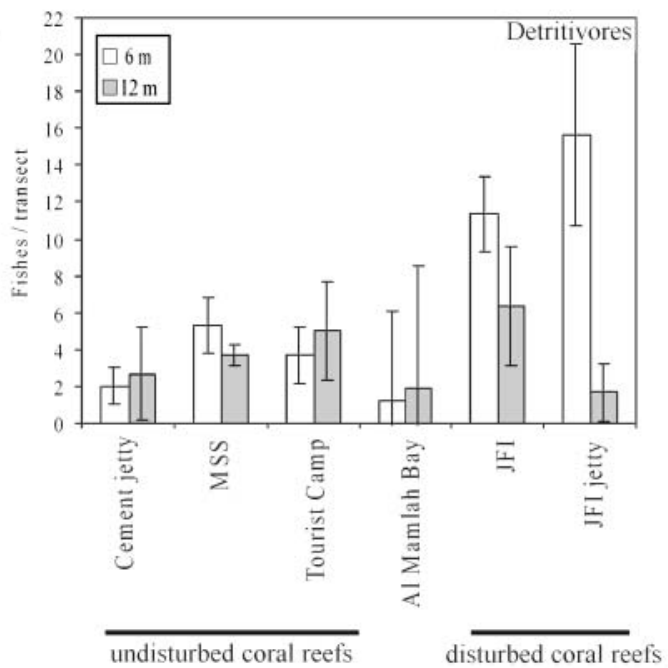

(E)

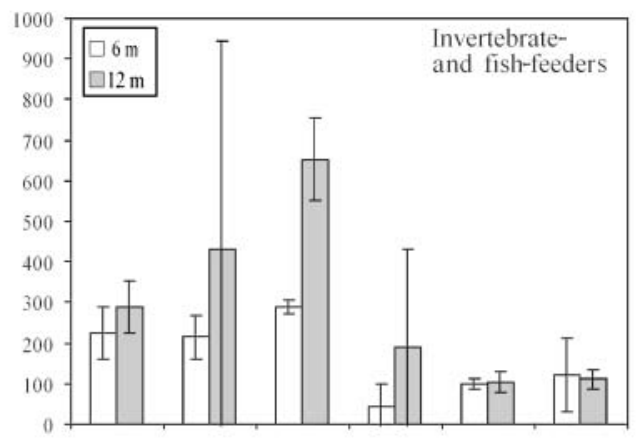

(F)

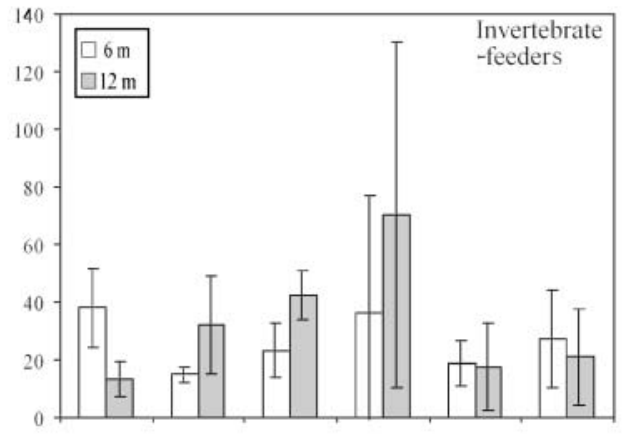

(G)

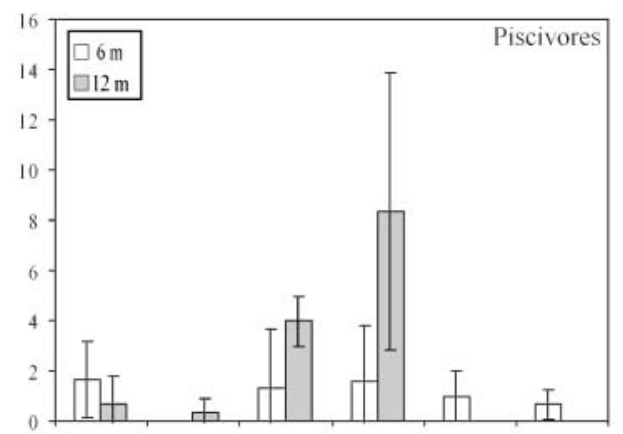

(H)

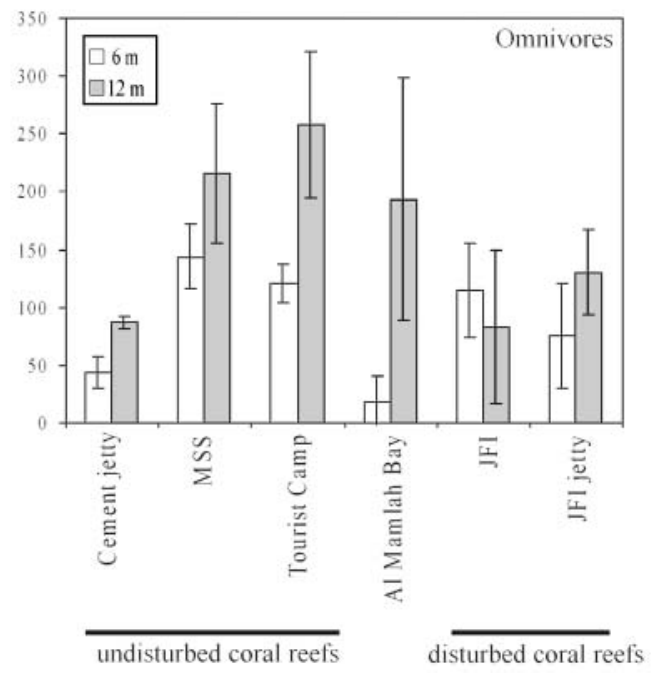

Fig. 3. Abundance of trophic fish groups (mean \pm SD) at sites along Jordanian Red Sea coast, Gulf of Aqaba. (A) corallivores; (B) planktivores; (C) herbivores; (D) detritivores; (E) invertebrate- and fish-feeders; (F) invertebrate-feeders; (G) piscivores; $(\mathrm{H})$ omnivores. Note different ordinate scales. JFI: Jordan Fertiliser Industries 
(A)

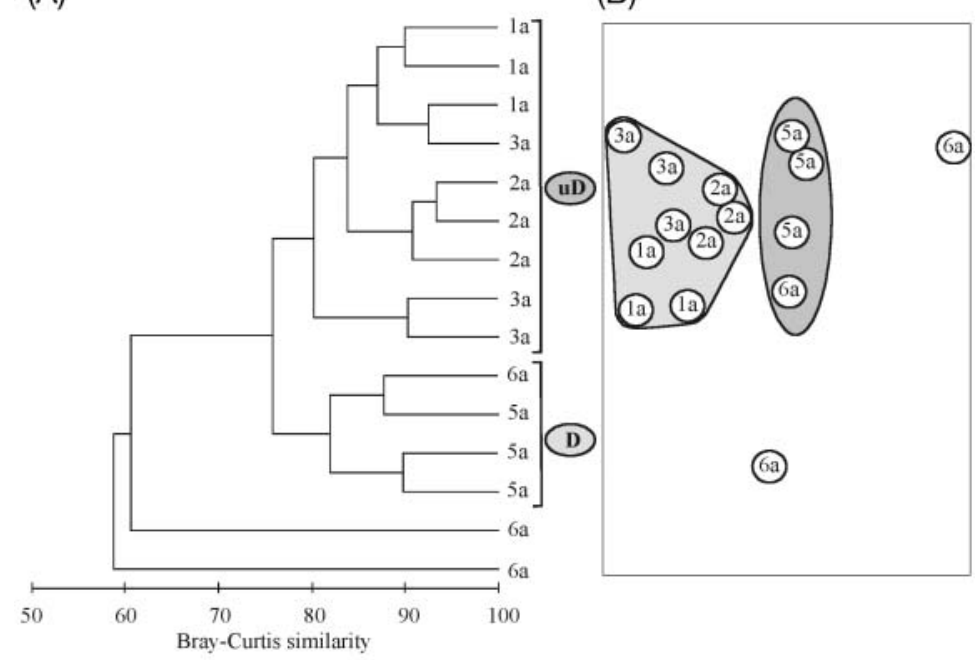

(C)

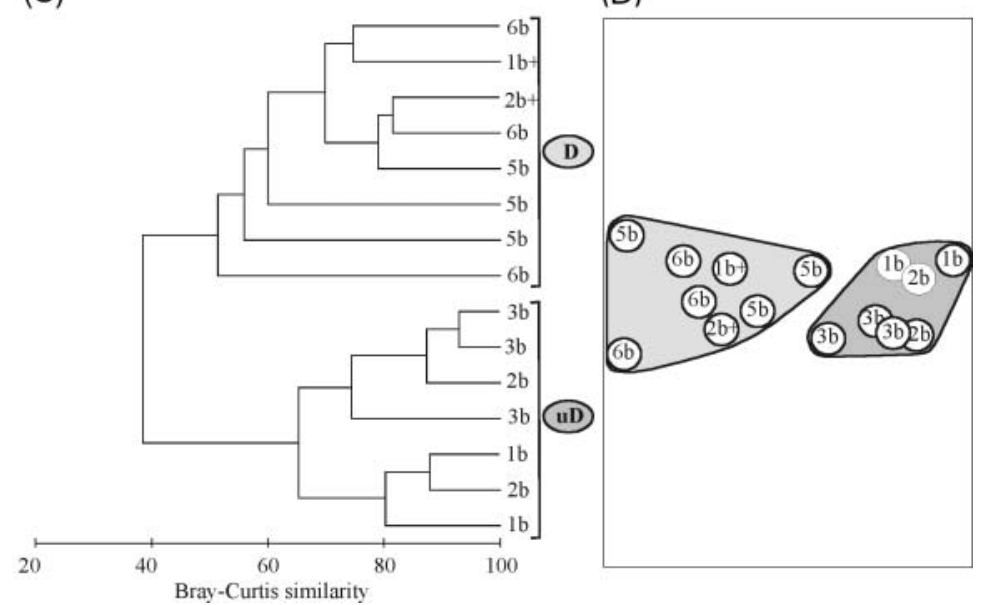

Fig. 4. Fish communities on disturbed and undisturbed coral reefs along Jordanian Red Sea coast, Gulf of Aqaba (based on abundance of feeding guilds-no pelagic or semi-pelagic species). (A, B) Dendrogram (A) and MDS plot (B) of shallow reef slope $(6 \mathrm{~m}$, Bray-Curtis similarity, standardisation, group average $;$ stress $=0.05$; ANOSIM: global $\mathrm{R}=0.0553, \mathrm{p}<0.001) ;(\mathrm{C}, \mathrm{D})$ dendrogram (C) and MDS plot (D) of deep reef slope (12 m, Bray-Curtis similarity, group average $;$ stress $=0.04 ;$ ANOSIM: global $\mathrm{R}=0.493$, $\mathrm{p}=0.004)$. Sites numbered as in Fig. $1(\mathrm{a}=6 \mathrm{~m}$ depth, $\mathrm{b}=12 \mathrm{~m}$ depth). D: disturbed coral reefs; $\mathrm{uD}$ : undisturbed coral reefs; +: mismatch

\& Kochzius 2002) revealed a strong spatial influence of habitat composition, but no temporal pattern. Studies on the colonisation of artificial reefs in Eilat (Rilov \& Benayahu 1998, Golani \& Diamant 1999) indicate that most recruitment takes place between January and May, with lower overall fish abundance in November. In contrast to these findings, total abundance was higher at the undisturbed sites in November than at the disturbed sites in March and April in our study. If temporal changes had been important, an opposite picture would have been expected. Therefore we can assume that temporal effects were not the reason for the observed differences.

Table 5. One-way ANOVA of abundance of feeding guilds at sites along Jordanian Red Sea coast, Gulf of Aqaba. Bold-face: significant p-values; ${ }^{*} \log (x+1)$-transformed data; iv: inhomogenous variances; S: seagrass-dominated habitat; CR: coral reef; ud: undisturbed coral reef; d: disturbed coral reef; abbreviations of feeding guilds as in Table 3

\begin{tabular}{|c|c|c|c|c|c|c|c|c|}
\hline \multirow{2}{*}{ Depth (habitat) } & \multicolumn{8}{|c|}{ - Feeding guilds } \\
\hline & $\mathrm{C}$ & $\mathrm{Pl}$ & $\mathrm{H}$ & $\mathrm{D}$ & IFF & IF & $\mathrm{Pi}$ & $\mathrm{O}$ \\
\hline \multirow[t]{2}{*}{$\mathrm{S}$ vs $\mathrm{CR}$} & $<0.001^{*}$ & iv & iv & $<0.001$ & 0.002 & $0.020^{*}$ & iv & iv \\
\hline & $\mathrm{S}<\mathrm{CR}$ & & & $\mathrm{S}<\mathrm{CR}$ & $\mathrm{S}<\mathrm{CR}$ & $\mathrm{S}>\mathrm{CR}$ & & \\
\hline \multirow[t]{2}{*}{12 m (S) vs 12 m (CR) } & $<0.001^{*}$ & $<0.001$ & $0.124^{*}$ & $<0.001^{*}$ & 0.102 & $<0.001^{*}$ & $<0.001^{*}$ & 0.199 \\
\hline & $\mathrm{S}<\mathrm{CR}$ & $\mathrm{S}>\mathrm{CR}$ & & $\mathrm{S}<\mathrm{CR}$ & & $\mathrm{S}>\mathrm{CR}$ & $\mathrm{S}>\mathrm{CR}$ & \\
\hline \multirow[t]{2}{*}{6 m vs 12 m (CR) } & 0.106 & $0.009^{*}$ & $0.053^{*}$ & $0.885^{*}$ & 0.409 & 0.879 & 0.904 & 0.035 \\
\hline & & $6 \mathrm{~m}<12 \mathrm{~m}$ & & & & & & $6 \mathrm{~m}<12 \mathrm{~m}$ \\
\hline 6 m vs 12 m (S) & iv & $<0.001$ & $<0.001^{*}$ & 0.616 & iv & iv & $<0.001^{*}$ & iv \\
\hline ud vs d & 0.091 & $\begin{array}{c}6 \mathrm{~m}<12 \mathrm{~m} \\
0.094\end{array}$ & $\begin{array}{c}6 \mathrm{~m}>12 \mathrm{~m} \\
0.175\end{array}$ & $\begin{array}{c}\mathbf{0 . 0 3 5}^{*} \\
\text { ud }<\mathrm{d}\end{array}$ & $\begin{array}{l}<0.001^{*} \\
u d>d\end{array}$ & 0.245 & $\begin{array}{c}6 \mathrm{~m}<12 \mathrm{~m} \\
0.164^{*}\end{array}$ & 0.106 \\
\hline $6 \mathrm{~m}$ vs $12 \mathrm{~m}(\mathrm{~d})$ & 0.406 & 0.847 & $\begin{array}{c}\mathbf{0 . 0 0 1} \\
6 \mathrm{~m}>12 \mathrm{~m}\end{array}$ & $\begin{array}{c}\mathbf{0 . 0 0 1}^{*} \\
6 \mathrm{~m}>12 \mathrm{~m}\end{array}$ & 0.879 & 0.632 & $\begin{array}{c}\mathbf{0 . 0 2 2} \\
6 \mathrm{~m}>12 \mathrm{~m}\end{array}$ & 0.691 \\
\hline 6 m (ud) vs 6 m (d) & 0.090 & iv & $\begin{array}{l}<0.001 \\
\mathrm{ud}<\mathrm{d}\end{array}$ & $\begin{array}{l}<0.001 \\
\text { ud }<\text { d }\end{array}$ & $\begin{array}{l}<0.001 \\
u d>d\end{array}$ & 0.744 & 0.857 & 0.763 \\
\hline 12 m (ud) vs 12 m (d) & iv & $\begin{array}{r}\mathbf{0 . 0 1 4} \\
u d>d\end{array}$ & 0.230 & 0.878 & iv & 0.242 & 0.058 & 0.072 \\
\hline
\end{tabular}


Fig. 5. Trophic composition of the fish fauna on disturbed and undisturbed coral reefs along Jordanian Red Sea coast, Gulf of Aqaba. (A) Shallow reef slope $(6 \mathrm{~m}) ;(\mathrm{B})$ deep reef slope $(12 \mathrm{~m})$
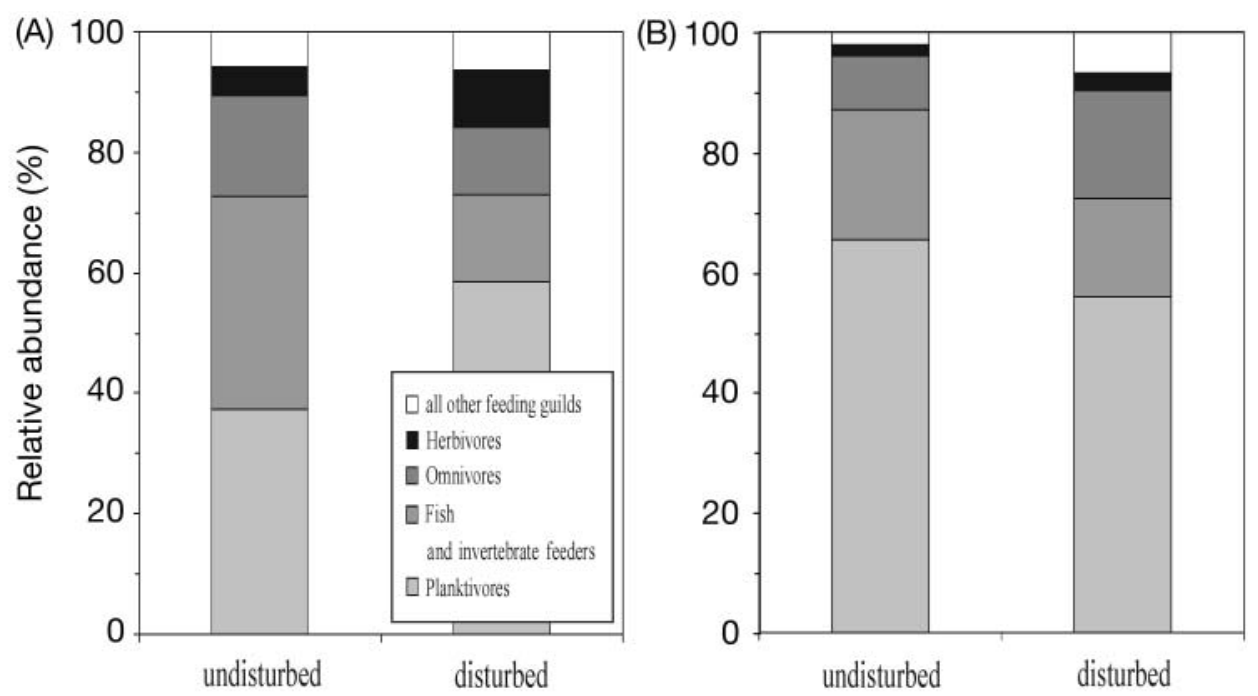

\section{Trophic structure of the community}

Planktivore fishes dominate the fish community on coral reefs in the Gulf of Aqaba. This finding corresponds with studies in Sri Lanka, the Great Barrier Reef, New Caledonia and the Gulf of Mexico (Williams \& Hatcher 1983, Öhman et al. 1997, Pattengill et al. 1997, Rossier \& Kulbicki 2000; Table 7). Zooplankton as a source of food, at least for diurnally active fishes, is fairly independent of the benthic habitat composition. Similar pattern of transport of the zooplankton result in a consistent dominance of planktivorous fishes on different coral reefs.

A comparison of our results with those of other studies revealed differences in the ranking and relative abundance of the other feeding guilds (Table 7). In Sri Lanka, New Caledonia, the Great Barrier Reef and the Gulf of Mexico, herbivores contribute a much higher proportion (2 to 7 times higher) to the fish community than they do in the Gulf of Aqaba. The relative abundance of herbivorous fishes was even lower at the seagrass-dominated site in the Gulf of Aqaba (Tables 4 $\& 7$ ) than on the coral reef sites in other parts of the world.
Table 6. Contribution of feeding guilds to community shift between disturbed and undisturbed coral reefs on the Jordanian Red Sea coast, Gulf of Aqaba (no transformation of data)

\begin{tabular}{|c|c|c|}
\hline \multirow[t]{2}{*}{ Feeding guild } & \multicolumn{2}{|c|}{ Contribution to dissimilarity ( $\%$ ) at } \\
\hline & $6 \mathrm{~m}$ depth & $12 \mathrm{~m}$ depth \\
\hline $\begin{array}{l}\text { Invertebrate- } \\
\text { and fish-feeders }\end{array}$ & 48.41 & 23.45 \\
\hline Planktivores & 41.27 & 64.19 \\
\hline Invertebrate-feeders & 4.22 & 1.13 \\
\hline Herbivores & 3.14 & 2.07 \\
\hline Omnivores & 1.72 & 7.37 \\
\hline Detritivores & 0.59 & 0.21 \\
\hline Unknown & 0.40 & 0.61 \\
\hline Corallivores & 0.19 & 0.68 \\
\hline Piscivores & 0.08 & 0.12 \\
\hline
\end{tabular}

The relative abundance of piscivores is more than 10-fold higher on the coral reefs in Sri Lanka, New Caledonia, the Great Barrier Reef and the Gulf of Mexico than on the Jordanian coast. These differences could be due to various factors such as prey availability, shelter and fishing, but could also be due to

Table 7. Relative abundance (\%) of feeding guilds of fishes on coral reefs

\begin{tabular}{|c|c|c|c|c|c|}
\hline Feeding guild & Aqaba $^{a}$ & Sri Lanka ${ }^{b}$ & Great Barrier Reef ${ }^{\mathrm{C}}$ & New Caledonia ${ }^{\mathrm{d}}$ & Gulf of Mexico \\
\hline Corallivores & 0.8 & 1.3 & & & \\
\hline Herbivores & 3.4 & 12.0 & 6.6 & 14.3 & $11.7-23.0$ \\
\hline Planktivores & 58.1 & 81.0 & 85.0 & 65.0 & 65.0 \\
\hline Omnivores & 11.6 & 1.5 & & & \\
\hline Piscivores & 0.1 & 2.5 & 3.6 & 1.0 & $1.3-2.8$ \\
\hline
\end{tabular}


Table 8. Trophic composition (\%) of fish assemblages on coral reefs. ${ }^{*}$ : sessile invertebrate browsers. No. of scleractinian coral species is also shown

\begin{tabular}{|c|c|c|c|c|c|c|c|c|c|c|c|}
\hline Feeding guild & $\operatorname{Aqaba}^{a}$ & Eilat $^{\mathrm{b}}$ & $\begin{array}{l}\text { Sanganeb } \\
\text { atoll }^{c}\end{array}$ & $\begin{array}{l}\text { b Sri } \\
\text { Lanka }^{d}\end{array}$ & $\begin{array}{l}\text { Great Barrier } \\
\text { d } \text { Reef }^{\text {e }}\end{array}$ & Tulear & Moorea $^{f}$ & Moorea $^{g}$ & $\begin{array}{r}\text { Reunion }^{9} \\
\text { C }\end{array}$ & $\begin{array}{l}1^{9} \text { New } \\
\text { Caledoniag }\end{array}$ & $\begin{array}{l}\text { Gulf of } \\
\text { Mexico }^{\mathrm{h}}\end{array}$ \\
\hline Corallivores & 3.5 & 3.5 & 7.4 & 8.1 & 4.6 & $6.2^{*}$ & $8.9^{*}$ & 11.0 & 7.0 & 8.0 & \\
\hline Herbivores & 8.6 & 10.6 & 7.4 & 20.7 & 14.9 & 10.1 & 15.4 & 3.0 & 2.5 & 4.0 & 15.0 \\
\hline Planktivores & 20.8 & 18.3 & 24.6 & 13.3 & 19.8 & 10.3 & 9.6 & 10.0 & 8.0 & 13.0 & 13.1 \\
\hline Detritivores & 1.0 & 0.7 & 0.0 & 3.0 & & & & 2.5 & 3.0 & 3.0 & \\
\hline Invertebrate- and & 14.1 & 10.6 & 10.7 & 8.9 & 1 & 1 & ) & 1 & 1 & ) & ) \\
\hline $\begin{array}{l}\text { fish-feeders } \\
\text { Invertebrate-feeder }\end{array}$ & 25.3 & 22.5 & 22.1 & 20.7 & 52.6 & 53.8 & 45.0 & 40.5 & 46.0 & 38.5 & 18.3 \\
\hline Piscivores & 4.0 & 5.6 & 5.7 & 14.1 & 8.1 & 4.0 & 5.7 & 7.0 & 12.5 & 10.0 & 28.8 \\
\hline Omnivores & 19.2 & 19.7 & 18.0 & 11.1 & & 15.6 & 15.4 & 26.0 & 21.0 & 23.5 & \\
\hline Unknown & 3.5 & 8.5 & 4.1 & & & & & & & & 24.8 \\
\hline $\begin{array}{l}\text { Scleractinian coral } \\
\quad \text { species (n) }\end{array}$ & $138^{\mathrm{i}}$ & & $146^{\mathrm{i}}$ & $118^{\mathrm{j}}$ & $212^{\mathrm{k}}$ & & $72^{1}$ & & $120^{\mathrm{m}}$ & $108^{\mathrm{n}}$ & \\
\hline
\end{tabular}

methodological differences. Öhman et al. (1997) restricted their fish counts to 135 species, and Williams \& Hatcher (1983) used explosive charges for sampling.

Besides relative abundance, the trophic species composition also reflects the trophic structure of the community (Table 8). Invertebrate feeders are the dominant feeding guild on coral reefs in terms of species richness (Jones et al. 1991), followed by planktivores and omnivores. Detrives comprise only a minor proportion of the ichthyofauna on coral reefs. The number of herbivores varies considerably within the fish communities of different geographical regions, and seems to be much lower around the oceanic islands of Moorea and Réunion and in New Caledonia.

The proportion of species belonging to particular feeding guilds is very similar between the 3 sites in the Red Sea (Aqaba, Eilat, Sanganeb atoll: Table 8), but differs somewhat from sites in the Indian and Pacific Oceans and the Gulf of Mexico (Table 8). The contribution of planktivorous species to fish assemblages in the Red Sea seems to be high in comparison to other coral reefs in the world, whereas piscivores play only a minor role. At the northern tip of the Gulf of Aqaba, the percentage of corallivorous species is only about half that in the central Red Sea and reefs in other parts of the Indo-Pacific. This might be due to lower scleractinian species richness in the Gulf compared to the central Red Sea (Antonius et al. 1990). However, no general correlation between the number of scleractinian corals and percentage of corallivorous species of a fish assamblage could be detected in the present study (Table 8).
Comparing the trophic structure of the ichthyofauna at the Jordanian coast with that of other coral reefs, we can conclude that: (1) the high relative abundance of planktivores is a general feature of the community structure of fishes on coral reefs; (2) most species on coral reefs are invertebrate feeders; (3) the relative abundance of feeding guilds other than planktivores seems to be strongly influenced by the benthic habitat; (4) the trophic species structure of fish communities on Red Sea coral reefs seems to be different from that on reefs in other parts of the Indo-Pacific Ocean.

\section{Comparison between coral reefs and seagrass-dominated site}

The reduced abundance of corallivores in the seagrass-dominated site at Al-Mamlah Bay is not surprising, since these fishes are strongly associated with live stony corals (Bouchon-Navaro et al. 1985, Jennings et al. 1996, Öhman \& Rajasuriya 1998, Khalaf \& Kochzius 2002). Despite the low coral cover and reduced shelter in AlMamlah Bay, the abundance of planktivorous fishes at $12 \mathrm{~m}$ depth is much higher than at all other study sites. In addition, the rich crustacean fauna of the seagrass meadows can support more invertebrate-feeders than coral reefs. Nocturnal feeding migrations of invertebratefeeders from coral reefs into seagrasses are documented for the Atlantic as well as the Indo-Pacific (Weinstein \& Heck 1979, Bell \& Pollard 1989, Kochzius 1999). The higher prey availability at the seagrass-dominated AlMamlah correlates with a higher abundance of piscivores in the bay than at the coral reef sites. 


\section{Human impact}

Univariate measures such as species richness, diversity and evenness were not able to demonstrate a negative impact of the industrial complex on the coral reef ichthyofauna. This situation is not uncommon, and has been reported in studies on the effect of coral mining (Shepherd et al. 1992) and coral bleaching (Lindahl et al. 2001). Investigations into the impact of dredging revealed a significant reduction in species richness on some reefs in French Polynesia, whereas other sites showed no difference from undredged areas (Harmelin-Vivien 1992). However, experimental coral disturbance led to a significant decline in fish species richness on the Great Barrier Reef (Lewis 1997). The higher diversity and evenness at the disturbed sites in the present study could be explained by the intermediate disturbance hypothesis (Connell 1978), i.e. an initial increase in diversity with increasing disturbance followed by a decrease at high levels of disturbance.

The abundance of fishes on disturbed reefs was half that on undisturbed reefs. In other geographical areas, significant declines in fish abundance have been caused by coral mining (Shepherd et al. 1992: the Maldives), turbidity and sedimentation due to dredging (Amesbury 1981: eastern Caroline islands), eutrophication (Chabanet et al. 1995: Indian Ocean) and experimental coral disturbance (Lewis 1997: Great Barrier Reef). However, disturbance by dredging in Moorea and Tahiti led to a decrease in fish abundance at some sites, whereas other reefs showed no significant difference (Harmelin-Vivien 1992). Mass mortality of bleached corals in Tanzania even triggered an increase in fish abundance, due to algal growth which supported a higher standing stock of herbivores (Lindahl et al. 2001).

Analysis of the trophic structure is very important when examining changes in the fish community due to human-induced disturbance. In our study, a higher abundance of detritivores was found on disturbed coral reefs, whereas the number of invertebrate- and fishfeeders was higher on undisturbed reefs. The reduction in invertebrate- and fish-feeders at disturbed sites can be explained by the loss of habitat structure due to degradation. The associated prey fauna of this feeding guild is reduced, and the disturbed reef cannot support a high number of invertebrate- and fish-feeders.

Herbivores were more abundant on the shallow slope of disturbed than undisturbed reefs, indicating a higher biomass of macroalgae on the slope. An increase in abundance of herbivorous fishes was reported after an increase in soft algae on Caribbean coral reefs, due to mass mortality of competing sea urchins (Robertson 1991). An increase in the abundance of some certain herbivorous fish species on degraded coral reefs has been described for bleached reefs by Lindahl et al. (2001) and after experimental coral disturbance by Lewis (1998). In contrast, no change in the abundance and biomass of some herbivores was detected on reefs impacted by the crown-ofthorns starfish Acanthaster planci with subsequent algal overgrowth (Hart et al. 1996).

There was a shift in the trophic composition of the ichthyofauna forwards planktivores on the shallow slope of disturbed reefs in our study. This could be due to the independence of planktivores from the benthic substrate in terms of food availability. Onshore transport of zooplankton depends on the oceanographic conditions and not on the condition of the reef. As long as enough shelter is available, these species can survive on a degraded coral reef (Lindahl et al. 2001). On the deep slope of the disturbed reefs in the present study, omnivores increased in relative abundance. This guild of fishes consisted of non-specialised feeders more able to cope with changes in the benthic habitat than invertebrate- and fish-feeders.

Apart from trophic considerations, recruitment to the degraded reef could also be reduced, through decreased settlement due to habitat loss or through higher mortality due to loss of shelter space (Shulman 1985, Schmitt \& Holbrook 1999).

In summary, the following changes in the fish community were recorded on the coral reef fronting the industrial complex: (1) $50 \%$ reduction in fish abundance; (2) increased total abundance of herbivorous and detritivorous fishes; (3) decreased total abundance of invertebrate- and fish-feeders; (4) resultant changes in the trophic composition, such as increased relative abundance of planktivores.

These changes are probably the synergetic effects of coastal constructions, sedimentation, nutrient input, algal growth, coral destruction and heavy metal load. In the course of future urbanisation and industrialisation of the Jordanian Red Sea coast, increased coastal pollution is expected. Because of the short (27 km long) coastline, future industrial development should be restricted to already industrialised areas, in order to preserve the remaining coral reefs and seagrass meadows. Marine reserves such as the Red Sea Marine Peace Park and regional co-operation between countries bordering the Gulf of Aqaba are important for the protection of coastal ecosystems.

Acknowledgements. We would like to express our thanks to the foundations, institutions and to the individuals that have made our work possible: director and staff of the Marine Science Station, in particular O. Al-Momani for assistance in diving, and M. Badran for his comments on the manuscript; Authority of the Aqaba Special Economic Zone; Office of Ocean and Coastal Resource Management (OCRM/NOS, NOAA) and USAID; M. Crospy (NOOA); Red Sea Programme 
on Marine Sciences (RSP), funded by the German Federal Ministry of Education and Research (BMBF, grant no. 03F0151A); Centre for Tropical Marine Ecology (ZMT), in particular G. Hempel and C. Richter for improving the manuscript with their comments; M. Birkicht for assistance in statistical analysis; P. Westhaus-Ekau for logistical support.

\section{LITERATURE CITED}

Abelson A, Shteinman B, Fine M, Kaganovsky S (1999) Mass transport from pollution sources to remote coral reefs in Eilat (Gulf of Aqaba, Red Sea). Mar Pollut Bull 38:25-29

Abu-Hilal AH (1985) Phosphate pollution in the Jordan Gulf of Aqaba. Mar Pollut Bull 16:281-285

Abu-Hilal AH (1987) Distribution of trace elements in nearshore surface sediments from the Jordan Gulf of Aqaba (Red Sea). Mar Pollut Bull 18:190-193

Abu Hilal AH (1997) Effects of coastal zone development and management on the coral reefs of the Jordan Gulf of Aqaba (Red Sea). In: NOAA (ed) Report of the Middle East Seas Regional Strategy Workshop for the International Coral Reef Initiative. Aqaba, Jordan, 21-25 September 1997. National Oceanic and Atmospheric Administration, Silver Springs, MD

Abu-Hilal AH, Badran MM (1990) Effect of pollution source on metal concentration in sediment cores from the Gulf of Aqaba. Mar Pollut Bull 21:190-197

Adjeroud M (1997) Factors influencing spatial patterns on coral reefs around Moorea, French Polynesia. Mar Ecol Prog Ser 159:105-119

Al-Moghrabi (2001) Unusual black band disease (BBD) outbreak in the northern tip of the Gulf of Aqaba (Jordan). Coral Reefs 19:330-331

Amesbury SS (1981) Effects of turbidity on shallow-water reef fish assemblages in Truk, eastern Caroline Islands. Proc 4th Int Coral Reef Symp 1:155-159

Antonius A, Scheer G, Bouchon C (1990) Corals of the Eastern Red Sea. Atoll Res Bull 334:1-22

Badran MI, Foster P (1998) Environmental quality of the Jordanian coastal waters of the Gulf of Aqaba, Red Sea. Aquat Ecosyst Health Manag 1:75-89

Bell JD, Pollard DA (1989) Ecology of fish assemblages and fisheries associated with seagrasses. In: Larkum AWD, McComb AJ, Shepherd SA (eds) Biology of seagrasses: a treatise on the biology of seagrasses with special reference to the Australian region. Elsevier, Amsterdam, p 565-609

Bell PRF (1992) Eutrophication and coral reefs-some examples in the Great Barrier Reef lagoon. Water Res 26: $553-568$

Bouchon C (1981) Quantitative study of the scleractinian coral communities of a fringing reef of Réunion Island (Indian Ocean). Mar Ecol Prog Ser 4:273-288

Bouchon-Navaro Y, Bouchon C, Harmelin-Vivien ML (1985) Impact of coral degradation on a chaetodontid fish assemblage (Moorea, French Polynesia). Proc 5th Int Coral Reef Congr 5:427-432

Brock RE (1982) A critique of the visual census method for assessing coral reef fish populations. Bull Mar Sci 32: 269-276

Chabanet P, Dufor V, Galzin R (1995) Disturbance impact on reef fish communities in Réunion Island (Indian Ocean). J Exp Mar Biol Ecol 188:29-48

Clarke KR, Warwick RM (1994) Changes in marine communities: an approach to statistical analysis and interpretation. Natural Environment Research Council, Swindon, UK
Connell JH (1978) Diversity in tropical rain forests and coral reefs. Science 199:1302-1309

Done TJ (1982) Patterns in the distribution of coral communities across the Central Great Barrier Reef. Coral Reefs 1: 95-107

English C, Wilkinson C, Baker V (1994) Survey manual for tropical marine resources. Australian Institute of Marine Science, Townsville, QD

Fishelson L (1973) Ecology of coral reefs in the Gulf of Aqaba (Red Sea) influenced by pollution. Oecologia 12:55-67

Gladstone W, Tawfiq N, Nasr D, Andersen I, Cheung C, Drammeh H, Krupp F, Lintner S (1999) Sustainable use of renewable resources and conservation in the Red Sea and Gulf of Aden: issues, needs and strategic actions. Ocean Coast Manag 42:671-697

Golani D, Diamant A (1999) Fish colonization of an artificial reef in the Gulf of Eilat, northern Red Sea. Environ Biol Fish 54:275-282

Harmelin-Vivien ML (1989) Reef fish community structure: an Indo-Pacific comparison. In: Harmelin-Vivien ML, Bourlière F (eds) Vertebrates in complex tropical systems. Springer-Verlag, Berlin, p 21-60

Harmelin-Vivien M (1992) Impact des activités humaines sur les peuplements ichthyologiques des récifes coralliens de Polynésie Française. Cybium 16:279-289

Hart AM, Klumpp DW, Russ GR (1996) Response of herbivorous fishes to crown-of-thorns starfish Acanthaster planci outbreaks. II. Density and biomass of selected species of herbivorous fish and fish-habitat correlations. Mar Ecol Prog Ser 132:21-30

Hawkins JP, Roberts CN (1994) The growth of coastal tourism in the Red Sea: present and future effects on coral reefs. Ambio 23:503-508

Jennings S, Boullé DP, Polunin NVC (1996) Habitat correlates of the distribution and biomass of Seychelles' reef fishes. Environ Biol Fishes 46:15-25

Jones GP, Ferrell DJ, Sale PF (1991) Fish predation and its impacts on the invertebrates of coral reefs and adjacent sediments. In: Sale PF (ed) The ecology of fishes on coral reefs. Academic Press, San Diego, p 156-179

Khalaf MA, Disi AM (1997) Fishes of the Gulf of Aqaba. Marine Science Station, Aqaba

Khalaf MA, Kochzius M (2002) Community structure and biogeography of shore fishes in the Gulf of Aqaba, Red Sea. Helgol Mar Res 55:252-284

Kochzius M (1999) Interrelation of ichthyofauna from a seagrass meadow and coral reef in the Philippines. In: Séret B, Sire J-Y (eds) Proc 5th Indo-Pacific Fish Conf (Nouméa, 3-8 November 1997). Société Française d'Ichthyologie and Institut de Recherche pour le Développement, Paris, p 517-535

Krupp F, Paulus T, Nasr D (1993) Coral reef fish survey. In: Krupp F, Türkay M, El Hag AGD, Nasr D (eds) Comparative ecological analysis of biota and habitats in littoral and shallow sublittoral waters of the Sudanese Red Sea. Project report. Forschungsinstitut Senckenberg, Frankfurt, and Faculty of Marine Science and Fisheries, Port Sudan, p 63-82

Letourneur Y, Kulbicki M, Galzin R, Harmelin-Vivien M (1997) Comparaison des peuplements de poissons marins des récifs frangeants de trois îles océaniques de l'IndoPacifique (La Réunion, Moorea et la Nouvelle-Calédonie). Cybium 21(Suppl):129-145

Lewis AR (1997) Effects of experimental coral disturbance on the structure of fish communities on large patch reefs. Mar Ecol Prog Ser 161:37-50

Lewis AR (1998) Effects of experimental coral disturbance on 
the population dynamics of fishes on large patch reefs. J Exp Mar Biol Ecol 230:91-110

Lindahl U, Öhman MC, Schelten CK (2001) The 1997/1998 mass mortality of corals: effects on fish communities on a Tanzanian coral reef. Mar Pollut Bull 42:127-131

Loya Y (1975) Possible effects of water pollution on the community structure of Red Sea corals. Mar Biol 29:177-185

Mahasneh D, Meinesz A (1984) Coastal management impact on the sublittoral zone of the Jordan coast of the Gulf of Aqaba. Proc Symp Coral Reef Env in the Red Sea, Jeddah, p 626-639

Mergner H (1981) Man-made influences on and natural changes in the settlement of the Aqaba reefs (Red Sea). Proc 4th Int Coral Reef Symp 1:193-207

Öhman MC, Rajasuriya A (1998) Relationships between structure and fish communities on coral and sandstone reefs. Environ Biol Fishes 53:19-31

Öhman MC, Rajasuriya A, Ólafsson E (1997) Reef fish assemblages in north-western Sri Lanka: distribution patterns and influence of fishing practises. Environ Biol Fishes 49: 45-61

Pattengill CV, Semmens BX, Gittings SR (1997) Reef fish structure at the Flower Gardens and Stetson Bank, NW Gulf of Mexico. Proc 8th Int Coral Reef Symp 1:1023-1028

Primer-E (2000) PRIMER 5. Plymouth Routines in Multivariate Ecological Research). PRIMER-E Ltd, Plymouth Marine Laboratory, Plymouth, UK

Rajasuriya A, Öhman MC, Johnstone RW (1998) Coral and sandstone reef-habitats in north-western Sri Lanka: patterns in the distribution of coral communities. Hydrobiologia 362:31-43

Riegl B, Velimirov B (1991) How many damaged corals in the Red Sea reef systems? A quantitative survey. Hydrobiologia 216/217:249-256

Rilov G, Benayahu Y (1998) Vertical artificial structures as an alternative habitat for coral reef fishes in disturbed areas. Mar Environ Res 45(4/5):431-451

Editorial responsibility: Gotthilf Hempel, Bremen, Germany
Rilov G, Benayahu Y (2000) Fish assemblages on natural versus vertical artificial reefs: the rehabilitation perspective. Mar Biol 136:931-942

Robertson DR (1991) Increase in surgeonfish populations after mass mortality of the sea urchin Diadema antillarum in Panamá indicate food limitation. Mar Biol 111:437-444

Rossier O, Kulbicki M (2000) A comparison of fish assemblages from two types of algal beds and coral reefs in the south-west lagoon of New Caledonia. Cybium 24:3-26

Schmitt RJ, Holbrook SJ (1999) Settlement and recruitment of three damselfish species: larval delivery and competition for shelter space. Oecologia 118:76-86

Shepherd ARD, Warwick RM, Clarke KR, Brown BE (1992) An analysis of fish community response to coral mining in the Maldives. Environ Biol Fishes 33:367-380

Shulman MJ (1985) Recruitment of coral reef fishes: effects of distribution of predators and shelter. Ecology 66:1056-1066

StatSoft (1997) STATISTICA for Windows 5.1, StatSoft, Tulsa

Thompson AA, Mapstone BD (1997) Observer effects and training in underwater visual surveys of reef fishes. Mar Ecol Prog Ser 154:53-63

UNEP/IUCN (United Nations Environment Programme/International Union for Conservation of Nature and Natural Resources) (1988) Coral reefs of the world. UNEP Regional Seas Directories and Bibliographies. IUCN, Gland, Switzerland, and Cambridge, UK, and UNEP, Nairobi, p 145-151

Walker DI, Ormond RFG (1982) Coral death from sewage and phosphate pollution at Aqaba, Red Sea. Mar Pollut Bull 13: 21-25

Weinstein MP, Heck, KL (1979) Ichthyofauna of seagrass meadows along the Caribbean coast of Panama and in the Gulf of Mexico: composition, structure and community ecology. Mar Biol 50:97-107

Williams D McB, Hatcher AI (1983) Structure of fish communities on outer slopes of inshore. mid-shelf and outer shelf reefs of the Great Barrier Reef. Mar Ecol Prog Ser 10:239-250

Submitted: May 3, 2001; Accepted: January 31, 2002

Proofs received from author(s): July 25, 2002 